\title{
Physical and Chemical Stressors on Algal, Invertebrate, and Fish Communities in 14 Milwaukee Area Streams, 2004-2013
}

\section{Introduction}

In 2004, the U.S. Geological Survey (USGS) began sampling 14 wadable streams in urban or urbanizing watersheds near Milwaukee, Wisconsin (fig. 1). The overall goal of the study is to assess the health of the aquatic communities in the Milwaukee Metropolitan Sewerage District planning area to inform current and future watershed management. In addition to collection of biological data on aquatic communities, physical and chemical data were also collected to evaluate effects of potential environmental stressors on the aquatic communities. This fact sheet summarizes the primary results of the study from 2004 to 2013. Detailed information is described in Scudder Eikenberry and others (2020a), and all data are available in Scudder Eikenberry and others (2020b; https://doi.org/10.5066/P9FWMODL).

Evaluations of aquatic communities using multiple groups of organisms - algal, invertebrate, and fish assemblages - and multiple measures or "metrics" of the groups are needed to fully understand environmental tolerances of the communities to chemical and physical stressors related to urban development (Coles and others, 2012). Each assemblage and each species have different tolerances to environmental stressors, different ranges of mobility, and different life spans. Algae reproduce quickly, living from days to weeks, and can indicate short-term changes in their environment. Algae form the base of the food web in streams and contribute to the processing of nutrients such as nitrogen and phosphorus, with excess nutrients often reflected by high algal biovolumes. Invertebrates are good indicators of water quality because of their relatively longer lifespans of months to years in comparison to algae, and their mostly stationary nature when compared to predators like fish make them indicative of sitespecific conditions. Fish generally live longer than other aquatic organisms, so fish assemblages integrate longer time periods of exposure to pollutants and other stressors. Fish are more mobile than invertebrates, so fish may better reflect conditions within a larger area, such as a watershed. Use of all three assemblages helps provide a complete picture of the health of the aquatic community and the overall stream condition.

Urban development can degrade streams physically and chemically through changes in characteristics such as streamflow, water quality, and habitat, which can in turn act as stressors on aquatic communities and adversely affect the overall ecological health of streams. Examples of stressors that can alter urban streams and aquatic communities in urban streams are increased runoff from impervious surfaces; straightening and armoring of natural streams; removal of trees and other vegetation along streams; and chemical inputs from sewage, road salt, and pesticides. Multiple lines of evidence, integrating key stressors and responses to them, are critical for understanding how different stressors adversely affect aquatic communities, which stressors are most important, and how the effects of those stressors may be lessened through watershed management actions. Long-term (10 years or more) monitoring of biological, physical, and chemical characteristics of streams provides a way to evaluate the effects of different stressors on aquatic communities.

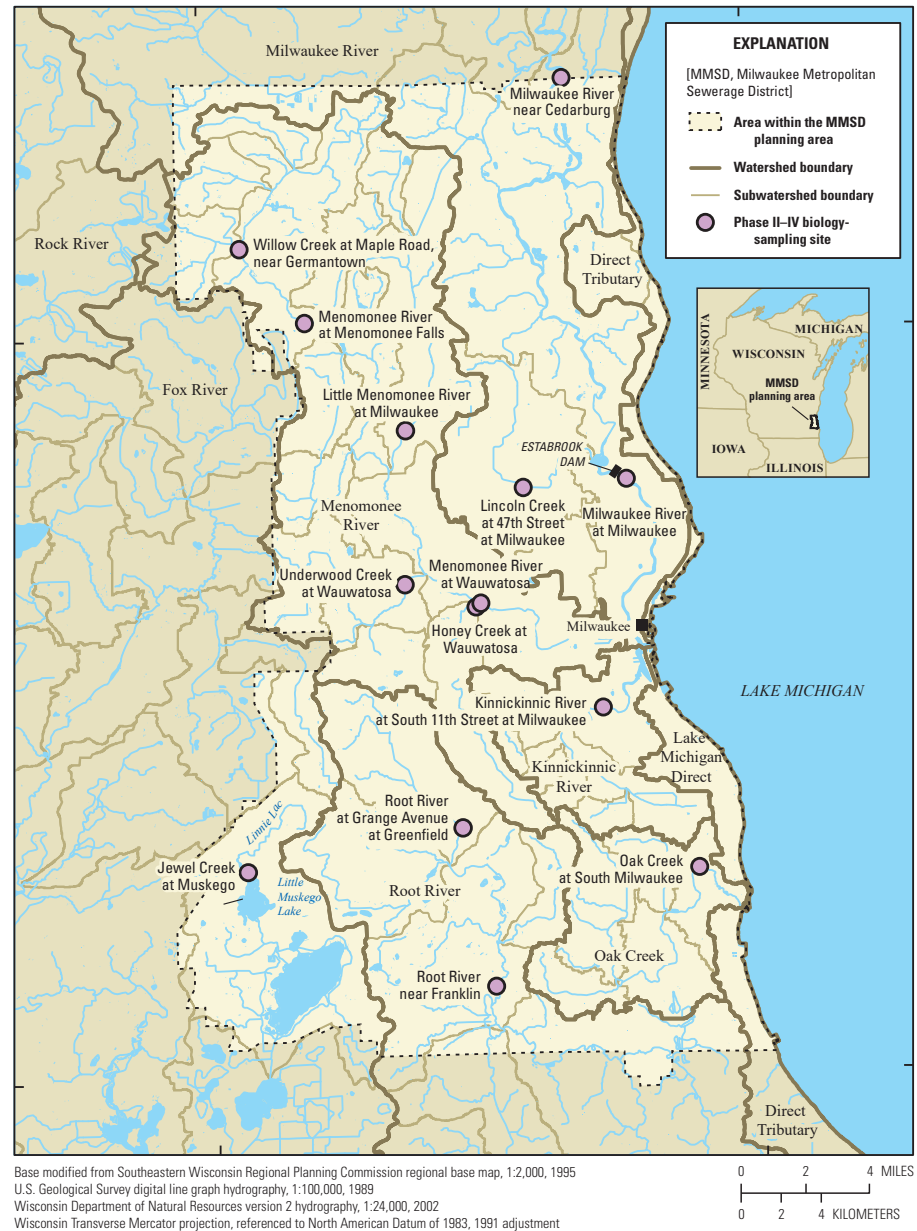

Figure 1. The U.S. Geological Survey has sampled aquatic communities every 3 years since 2004 at 14 sampling sites in the Milwaukee Metropolitan Sewerage District planning area of Wisconsin. 



\section{EXPLANATION}

MRC Milwaukee River near Cedarburg

LCM Lincoln Creek at 47th Street at Milwaukee

MRM Milwaukee River at Milwaukee

WCG Willow Creek at Maple Road, near Germantown

MRMF

LMM

UCW

HCW

MRW

KRM

OCSM

RRG

RRF

JCM
Menononee River at Menomonee Falls

Little Menomonee River at Milwaukee

Underwood Creek at Wauwatosa

Honey Creek at Wauwatosa

Menomonee River at Wauwatosa

Kinnickinnic River at South 11th Street at Milwaukee

Oak Creek at South Milwaukee

Root River at Grange Avenue at Greenfield

Root River at Franklin

Jewel Creek at Muskego
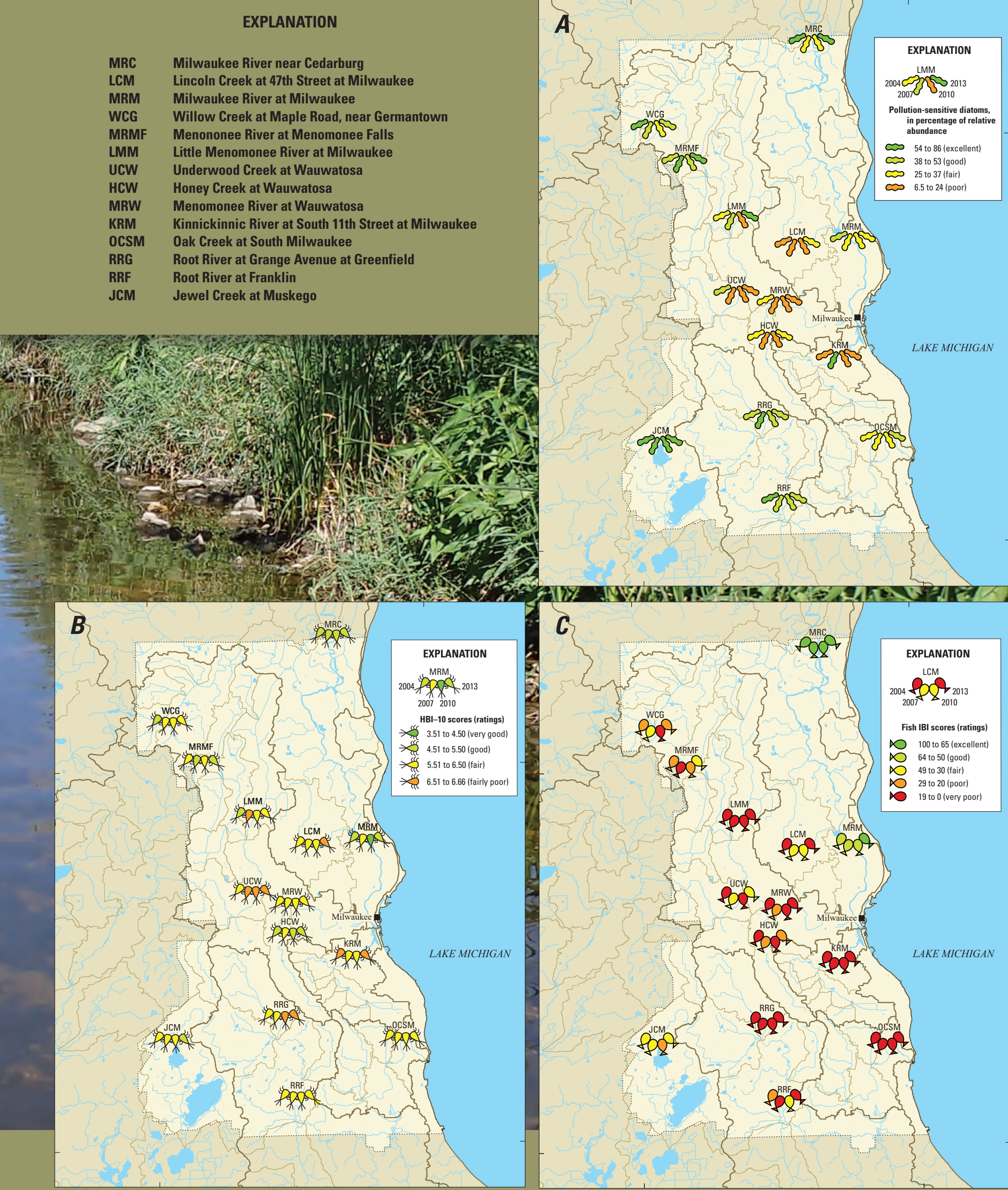

Figure 2. Results from 14 sampling sites in the Milwaukee Metropolitan Sewerage District planning area, Wisconsin, 2004-13 showing $A$, presence of pollution-sensitive diatoms; $B$, Hilsenhoff Biotic Index ratings for fall samples of invertebrates and $C$, Wisconsin Index of Biotic Integrity ratings for fish. 


\section{Aggregate Metrics Provide Insights to Overall Stream Stressors}

Metrics computed from the three assemblages (algae, invertebrates, and fish) together with species-specific pollution tolerances were used to gain a holistic view of differences in aquatic communities over the study period. These aggregate bioassessments indicated some level of degraded health at most of the 14 sites (table 1). The least degraded sites (in order, starting with the best overall condition) were the Milwaukee River near Cedarburg, Menomonee River at Menomonee Falls, Jewel Creek, and Milwaukee River at Milwaukee. The most degraded sites (in order, ending with the worst overall condition) were Menomonee River at Wauwatosa, Root River at Greenfield, Lincoln Creek, and the concrete-lined Kinnickinnic
River. Differences in aggregate bioassessments indicate that aquatic communities at the Menomonee River at Wauwatosa and the Root River at Greenfield were worse in 2013 than in 2004; however, communities at Oak Creek and Honey Creek sites were better in 2013. Results also indicate that the Menomonee River degrades downstream as the watershed becomes more urban from Menomonee Falls to Wauwatosa, and the Root River improves downstream as it becomes less urban from Greenfield to Franklin. Despite differences in outcomes for algal, invertebrate, and fish assessments at a few sites in 2013, use of all three assemblages provided the most robust evaluation of aquatic communities compared with single assemblage assessments because differences in pollution tolerances, mobility, and lifespans of all three assemblages were accounted for in the evaluation.

Table 1. Single (algae, invertebrate, and fish) and aggregate (site) bioassessment rankings for 14 sampling sites in the Milwaukee Metropolitan Sewerage District planning area, Wisconsin, in 2013 and 2004.

[The fill color indicates the group based on percentiles of the ranked data for single assemblages of aquatic organisms and for multiple assemblages aggregated for sites (group 1 or less than the 25th percentile [least degraded], blue; group 2 or between the 25th and 49th percentile/median, light blue; group 3 or between the 50th to 74th percentile, light orange; group 4 or greater than the 75 th percentile [most degraded], orange; each column is considered independently). Lower percentiles indicate better stream condition.]

\begin{tabular}{|c|c|c|c|c|c|}
\hline \multirow{2}{*}{ Site name } & \multicolumn{3}{|c|}{ Mean trophic-level ranking for 2013} & \multirow{2}{*}{$\begin{array}{l}\text { Aggregate bioas- } \\
\text { sessment ranking } \\
\text { for } 2013\end{array}$} & \multirow{2}{*}{$\begin{array}{l}\text { Aggregate bioas- } \\
\text { sessment ranking } \\
\text { for } 2004\end{array}$} \\
\hline & Algae $^{1}$ & Invertebrates $^{2}$ & Fish $^{3}$ & & \\
\hline \multicolumn{6}{|c|}{ Group 1} \\
\hline Milwaukee River near Cedarburg, Wisconsin & 5.0 & 1.7 & 1.0 & 2.56 & 1.44 \\
\hline Menomonee River at Menomonee Falls, Wisconsin & 3.0 & 3.3 & 3.0 & 3.11 & 5.44 \\
\hline Jewel Creek at Muskego, Wisconsin & 1.5 & 6.7 & 5.0 & 4.39 & 3.50 \\
\hline Milwaukee River at Milwaukee, Wisconsin & 10.5 & 5.0 & 2.0 & 5.83 & 3.56 \\
\hline \multicolumn{6}{|c|}{ Group 2} \\
\hline Little Menomonee River at Milwaukee, Wisconsin & 4.0 & 7.0 & 8.0 & 6.33 & 7.28 \\
\hline Root River near Franklin, Wisconsin & 4.5 & 5.7 & 9.0 & 6.39 & 6.39 \\
\hline Willow Creek at Maple Road near Germantown, Wisconsin & 9.5 & 6.7 & 6.0 & 7.39 & 6.33 \\
\hline \multicolumn{6}{|c|}{ Group 3} \\
\hline Oak Creek at South Milwaukee, Wisconsin & 4.0 & 7.7 & 12.0 & 7.89 & 9.61 \\
\hline Honey Creek at Wauwatosa, Wisconsin & 10.0 & 7.3 & 7.0 & 8.11 & 9.33 \\
\hline Underwood Creek at Wauwatosa, Wisconsin & 10.5 & 12.0 & 4.0 & 8.83 & 9.17 \\
\hline \multicolumn{6}{|c|}{ Group 4} \\
\hline Menomonee River at Wauwatosa, Wisconsin & 10.0 & 7.7 & 11.0 & 9.56 & 9.11 \\
\hline Root River at Grange Avenue at Greenfield, Wisconsin & 5.0 & 11.7 & 13.0 & 9.89 & 8.56 \\
\hline Lincoln Creek at 47th Street at Milwaukee, Wisconsin & 12.5 & 8.7 & 10.0 & 10.39 & 11.11 \\
\hline $\begin{array}{l}\text { Kinnickinnic River at South 11th Street at Milwaukee, } \\
\text { Wisconsin }\end{array}$ & 13.0 & 12.7 & 14.0 & 13.22 & 13.06 \\
\hline
\end{tabular}

${ }^{1}$ Averaged bioassessment rankings for algae included the percentage of most tolerant diatoms and the percentage of sensitive diatoms.

${ }^{2}$ Averaged bioassessment rankings for invertebrates included the Shannon index of diversity scores; the percentage of Ephemeroptera, Plecoptera, and Trichoptera taxa; and the Hilsenhoff Biotic Index scores, modified to limit the number of individuals per taxon to 10 for index computation.

${ }^{3}$ Averaged bioassessment rankings for fish included only Index of Biotic Integrity scores. 


\section{Summary}

Over the 10-year period from 2004 to 2013, differences in the health of aquatic communities and streams were seen for algal, invertebrate, and fish assemblages at the 14 streams sampled in the Milwaukee Metropolitan Sewerage District planning area. Among varying amounts of urban development, some assemblages and some stream ecosystems were better, some were worse, and others stayed fairly similar but were often in fair or poor condition. The variability in stressor effects across assemblages and time underscores the importance of long-term monitoring (more than 10 years) of physical, chemical, and biological components of streams using multiple assemblages to evaluate the effects of different stressors on aquatic communities and streams. Key urban-related stressors on all three assemblages were flashy runoff (as indicated by high peak streamflow) and untreated sewage (as indicated by high fecal coliform bacteria counts). An additional stressor on invertebrates and fish was high chloride concentrations with averages at some sites above the U.S. Environmental Protection Agency's chronic water-quality criterion for the protection of aquatic life. All three stressors reflected an urban signature connected to urban developed land in the watershed and along the stream and higher percentages of impervious surface in the watershed. These urban metrics were also significantly correlated with each other. Our results underscore the harmful effects of urban developed land on aquatic communities through runoff from impervious surfaces to nearby streams. These stressors must be reduced before overall biotic assemblages can improve; local stream habitat improvements will not be sufficient.
Fitzpatrick, F.A., Waite, I.R., D’Arconte, P.J., Meador, M.R., Maupin, M.A., and Gurtz, M.E., 1998, Revised methods for characterizing stream habitat in the National Water-Quality Assessment program: U.S. Geological Survey WaterResources Investigations Report 98-4052, 67 p. [Also available at https://doi.org/10.3133/wri984052.]

Hilsenhoff, W.L., 1998, A modification of the biotic index of organic stream pollution to remedy problems and permit its use throughout the year: Great Lakes Entomologist, v. 31 , p. $1-12$.

Lyons, J., 1992, Using the Index of Biotic Integrity (IBI) to measure environmental quality in warmwater streams of Wisconsin: St. Paul, Minn., U.S. Department of Agriculture, Forest Service, North Central Experiment Station, General Technical Report NC-149, 51 p.

Moulton, S.R., II, Kennen, J.G., Goldstein, R.M., and Hambrook, J.A., 2002, Revised protocols for sampling algal; invertebrate, and fish communities as part of the National Water-Quality Assessment Program: U.S. Geological Survey Open-File Report 02-150, 75 p. [Also available at https://doi.org/10.3133/ofr2002150.]

Porter, S.D., 2008, Algal attributes-An autecological classifi=cation of algal taxa collected by the National Water Quality Assessment Program: U.S. Geological Survey Data Series 329, https:/pubs.usgs.gov/ds/ds329/.

Scudder Eikenberry, B.C., Nott, M.A., Stewart, J.S., Sullivan, D.J., Alvarez, D.A., Bell, A.H., and Fitzpatrick, F.A., 2020a, Ecological status of aquatic communities in selected streams in the Milwaukee Metropolitan Sewerage District Planning Area of Wisconsin, 2004 - 2013: U.S. Geological Survey Scientific Investigations Report 2020-5035, 84 p. [Also avai able at https://doi.org/10.3133/sir20205035.]

Scudder Eikenberry, B.C., Nott, M.A., Stewart, J.S., Sullivan, D.J., Fitzpatrick, F.A., Bell, A.H., and Olds, H.T., 2020b, Aquatic community and environmental data for 14 rivers and streams in the Milwaukee Metropolitan Sewerage District planning area of Wisconsin, 2004-13: U.S. Geological Survey data release, https://doi.org/10.5066/P9FWMODL.
Coles, J.F., McMahon, G., Bell, A.H., Brown, L.R., Fitzpatrick, F.A., Scudder Eikenberry, B.C., Woodside, M.D., Cuffney, T.F., Bryant, W.L., Cappiella, K., Fraley-McNeal, L., and Stack, W.P., 2012, Effects of urban development on stream ecosystems in nine metropolitan study areas across the United States: U.S. Geological Survey Circular 1373, 138 p. [Also available at https://doi.org/10.3133/cir1373.]
By Barbara C. Scudder Eikenberry, Michelle A. Nott, Jana S. Stewart, Daniel J. Sullivan, David A. Alvarez, Amanda H. Bell, and Faith A. Fitzpatrick

\section{For more information about this publication contact:}

\author{
Director, USGS Upper Midwest Water Science Center \\ 8505 Research Way \\ Middleton, WI 53562 \\ (608) 828-9901
}

Publishing support provided by the

Madison/Indianapolis Publishing Service Center 